\title{
Threats to a small population: a census and conservation recommendations for wild buffalo Bubalus arnee in Nepal
}

\author{
Joel T. Heinen and Ramchandra Kandel
}

\begin{abstract}
We censused wild buffalo Bubalus arnee in Koshi Tappu Wildlife Reserve, Nepal, in March 2004 using methods employed in earlier surveys, and estimated a population of 159 animals. Since the last census in 2000 the management situation has deteriorated. Guard posts have been evacuated due to the Maoist insurgency. The entire Army Battalion usually posted in the Reserve was at Headquarters at the time of this study and therefore there were no patrols over most of the Reserve, and much human encroachment. Mortality from flooding and road deaths, and possibly poaching
\end{abstract}

for meat, were evident, and males suffered more mortality overall than females. Despite these threats the population had increased since 2000, albeit at a lower rate than previously. Active management, including interventions within the Reserve and a translocation of some individuals to Chitwan National Park, are recommended.

Keywords Asiatic wild buffalo, Bubalus arnee, Bubalus bubalis, Koshi Tappu Wildlife Reserve, Nepal, translocation.

\section{Introduction}

Although there is little information on the former or current status of Asiatic wild buffalo Bubalus arnee (=Bubalus bubalis; Groves, 1981), all populations are categorized as Endangered or Critically Endangered (Hedges, 1995; Heinen \& Srikosamatara, 1996; Read, 1999; IUCN, 2006) on the IUCN Red List. As the species has been in domestication for at least 4,500 years (Clutton-Brock, 1989) even the historical geographic range is uncertain. Buffalo occurred at least from South to South-east Asia but there is also evidence of them in the Indus Valley over 5,000 years ago (Nowak, 1999). There is genetic evidence that river and swamp breeds were separately domesticated from wild stocks that diverged between 15,000 (Barker et al., 1997) and over 1 million years ago (Amano et al., 1994). The two breeds could have been separate species, although the genetic evidence is unclear (Muley, 2001). Locations of putative wild stock are western Thailand, northern Myanmar, east and central India, southern Bhutan and south-eastern Nepal (Corbet \& Hill, 1992; IUCN, 2006).

Among extant populations that of Koshi Tappu Wildlife Reserve, Nepal, may contain pure wild stock, and a recent genetic study (Flamand et al., 2003) supported this view. This is probably also true of populations in Assam

Joel T. Heinen (Corresponding author) Department of Environmental Studies, Florida International University, Miami, FL, 33199, USA. E-mail heinenj@fiu.edu

Ramchandra Kandel Department of National Parks and Wildlife Conservation, GPO 860, Babar Mahal, Kathmandu, Nepal.

Received 11 April 2005. Revision requested 13 June 2005. Accepted 19 September 2005. and Madya Pradesh, India (Choudury, 1994) and a remnant population in western Thailand, although there is debate about the genetic integrity of some stocks (Divakar \& Bhusan, 1988). In spite of its importance in domestication, the species is poorly studied; the feral population in Australia is perhaps the best known (Tulloch, 1979). Because of the species' threatened status Nepal's Department of National Parks and Wildlife Conservation is concerned about the future prospects for buffalo in the country (Suwal, 1993; Shrestha, 1997).

The $175 \mathrm{~km}^{2}$ Koshi Tappu Wildlife Reserve in the floodplain of the Koshi River in Sunsari and Saptari Districts (75-100 m altitude) was established in 1976 as the only location in Nepal with wild buffalo (Figs 1 \& 2). It was designated Nepal's first Ramsar site in 1987 because of extensive wetlands and wintering waterfowl concentrations (Sah, 1997). It is subject to extreme flooding from June to September. Over $80 \%$ of the area is dominated by tall grasses (e.g. Saccharum and Phragmites) and beaches, with forests of Bombax, Dalbergia and Acacia elsewhere (Sah, 1997). With one of the highest human population densities in rural Nepal the area has had park-people conflicts since establishment (Heinen, 1993a).

Following a recent proposal to use wild buffalo semen for inseminating domestic stock (Karki, 2003) the Department of National Parks and Wildlife Conservation asked us to census the population in 2004. The last census was in 2000 (Heinen \& Singh, 2001) and, as a result of recent political volatility, there is concern for the status of buffalo in the Reserve. The Maoist insurgency (Thapa, 2003; Baral \& Heinen, 2006) led to a situation in which Army posted to protect parks and reserves turned its 




Fig. 1 Locations of all protected areas in Nepal. The five protected areas along the southern (Indo-Nepalese) border are within the historical geographical range of wild buffalo. NP, National Park; WR, Wildlife Reserve; CA, Conservation Area; HR, Hunting Reserve.

attention elsewhere, resulting in encroachment that jeopardizes conservation. Here we (1) describe the new census and compare it with earlier censuses, (2) assess the current management situation and any implications for buffalo conservation, and (3) make conservation recommendations for buffalo in Nepal.

\section{Methods}

For our purposes mixed herds (of which there are two, the northern and southern herds; Fig. 2) are composed of females and calves considered to be pure wild stock. Backcrossed herds are composed of females and calves that share most but not all phenotypic and behavioural characteristics of wild buffalo and are derived from domestic females that have interbred with wild males for at least 6 generations. One herd bull, whose tenure is under continual challenge from bachelors, generally accompanies each of these herds and there is a rapid turnover of herd bulls. Criteria for identifying wild buffalo from feral backcrosses were first used by Dahmer (1978) and then by JTH in other censuses (Heinen, 1993b; Heinen \& Singh, 2001; Heinen, 2002). We censused in March 2004, the month of all previous censuses (facilitating comparison of age structure across years), when visibility is highest and before the pre-monsoon heat.

We approached buffalo herds in a four-wheel drive vehicle, frequently stopping and surveying the landscape and walking up to $5 \mathrm{~km}$ to survey areas that prohibited vehicle access. We made repeated sightings of the mixed and backcrossed herds and a number of bachelor males, based on their locations and recognizable individuals. On 25 March we surveyed the main channel of the Koshi river by boat and recorded a backcrossed herd and additional bachelors. On 26 March we surveyed the active southern river channel on foot, and we recorded the southern herd, as well as more bachelors, and one backcrossed herd that was previously not counted. In total, we located and counted mixed herds at least twice and backcrossed herds at least once.

The tendency for bachelors to herd is variable (Dahmer, 1978). As bachelors are usually, but not necessarily, found in proximity to mixed or backcrossed female herds, we asked informants about the locations of known bulls around the periphery of the Reserve and distance from the female herds. Previous work showed that some bachelors spent much time living near and mating with domestic stock. Based on informants and field surveys, we found recent (within 1 month) evidence 


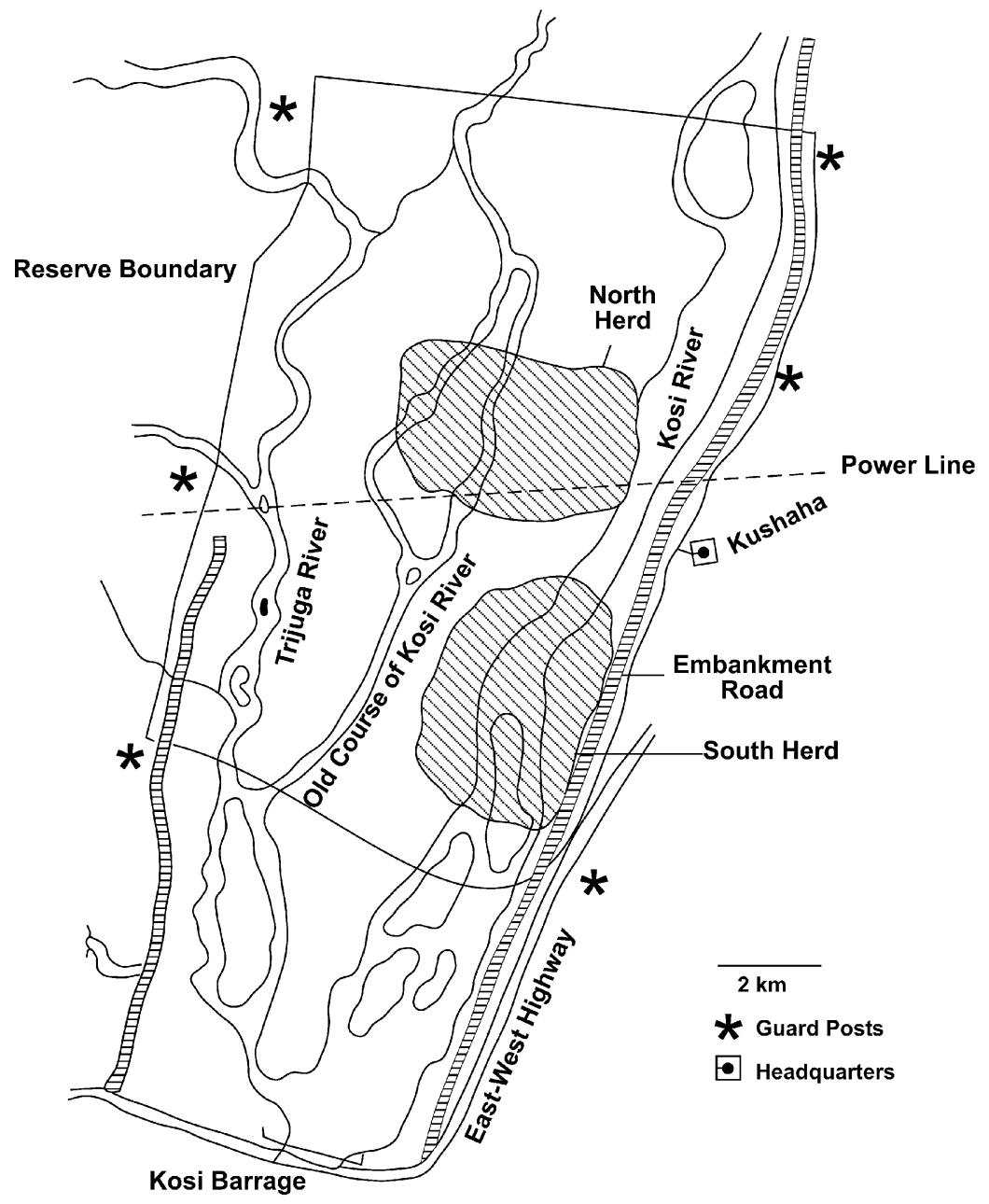

Fig. 2 A map of Koshi Tappu Wildlife Reserve showing the approximate courses of the Koshi, Old Koshi and Trijuga Rivers, Reserve Headquarters, guard posts, and approximate home ranges for the northern and southern wild buffalo (mixed) herds. of 10 wild bulls near the northern boundary $(>10 \mathrm{~km}$ from any wild herds), a few south of the southern boundary and several others along the western boundary ( $>3 \mathrm{~km}$ from any wild herds), which were added to census figures. The population growth rate was calculated per capita per year by the exponential growth formula $r_{\mathrm{i}}=\ln \left(N_{\mathrm{j}} / N_{\mathrm{k}}\right) t$, where $r_{\mathrm{i}}=$ growth rate calculated for that time interval, $N_{\mathrm{j}}=$ population size at the end of the interval, $N_{\mathrm{k}}=$ population size at the beginning of the interval, and $t=$ number of years in the interval.

We recorded mortality and injuries for wild and backcrossed stock and obtained records of human-induced buffalo mortality from 2000 to 2004 for which cases were filed. We also recorded cases and types of any human encroachment that we observed. We interviewed the former warden, Ganga Ram Singh, and Army and Reserve personnel for their reflections on the current management situation.

\section{Results}

\section{Population survey}

The population data show an apparent decline in the calf/cow ratio. Population growth $\left(r_{\mathrm{i}}\right)$ over the 28-year time period (Table 1) was high overall (0.033), but variable. It was high for 1976-1987 (0.033) and for 1988-2000 (0.037), but lower for 1987-1988 (0.022) and 2000-2004 (0.023). The adult sex ratio was female-biased in 1976 and again in 2004, but male-biased in the three intervening censuses.

High flood-related mortality of females and calves was apparent in the monsoon of 1987 when the Koshi River last made a full change of course. Of 16 first year calves recorded in the 1987 census, only eight lived into their second year (Table 1). This is the only time period for which a researcher (JTH) was resident for a 2-year period and for which there were consecutive annual censuses; several adult females also drowned that year (Heinen, 
1993b). Flood-related female mortality alone may explain the male-biased sex ratios in three of the five censuses. The earliest census (Dahmer, 1978) was more reflective of the demography of a natural population, although it could also reflect some male-biased trophy hunting before the Reserve was protected in 1976.

\section{Management of Koshi Tappu Wildlife Reserve}

Male mortality is high (Table 2), which may be indicative of male-biased human-induced mortality. The Army Battalion relocated to the headquarters at Kusaha in 2002 (Reserve records, 2003) and the result was evident in 2004: patrols were seen regularly along the eastern embankment but nowhere inside the Reserve or along its other boundaries. We encountered many illegal activities, including fishermen along the main and old channels of the Koshi River. Villagers along the western side of the Reserve are permitted to bring livestock to the Trijuga River for water but we encountered large numbers of tended cattle and buffalo from the western boundary to the east of the Trijuga (Fig. 2). With no patrols, villagers were grazing livestock inside the Reserve. We also encountered evidence of much illegal cutting of medium and large khair Acacia catechu trees; all groves seen in 2004 had recently-cut individuals.

One situation had improved in the Reserve. The Army began shooting buffalo of domestic origin in 2001. By March 2004, 167 buffalo had been shot inside the Reserve (Reserve records, 2005). The number of backcrossed (either feral or tended) buffalo in 2004 compared with earlier was lower as a result (Table 3). Many of these animals are kept in a semi-wild or tended, free-ranging state to crossbreed with wild males because hybrid calves fetch higher prices (Heinen, 1993b). As wildlife officials accompanied soldiers during this culling there is no evidence that wild animals were shot by mistake (G.R. Singh, former warden, pers. comm.). However, this policy was controversial because some domestic animals were killed that had been grazing in the Reserve illegally, and the Army has since halted the culling. An order was posted to remove all domestic cattle from the Reserve in
Table 2 Known wild buffalo deaths from 2000 to 2004, based on records kept at Koshi Tappu Wildlife Reserve. More males than females were confirmed dead and most deaths were suspected or known to be human-caused.

\begin{tabular}{llll}
\hline Date & Sex/Age & Cause & Place \\
\hline Dec. 2000 & Adult male & Poison? & Cane field \\
Feb. 2001 & Adult female & Old age & Reserve \\
July 2002 & Adult male & Road kill & Highway \\
Sep. 2002 & Pregnant female & Poison? & Haripur \\
Sep. 2002 & Adult male & Poison? & Cane field \\
Oct. 2002 & Male calf & Natural & Reserve \\
Nov. 2002 & Adult male & Road kill & Highway \\
Feb. 2003 & Adult male & Road kill & Highway \\
Sep. 2003 & Adult male & Poison? & Rice field \\
Oct. 2003 & Adult male & Poison? & Cane field \\
Jan. 2004 & Adult male & Poison & Rice field \\
\hline
\end{tabular}

2004, and this was underway during our census. By the end of March over 2,000 cattle had been removed, but we encountered hundreds more inside the Reserve. As cattle cannot be killed in Nepal because of their sacred status this problem will need continual monitoring. Lastly, there were no records of people killed by buffalo over the previous 4 years, but two men and one girl were injured. One man and the girl were attacked outside the Reserve and the other man was illegally inside the Reserve.

\section{Discussion}

Comparing our 2004 results with previous censuses (Table 1) facilitates interpretation of several facets of population dynamics. However, as censuses were made on five occasions at four uneven intervals over a 28 -year period some interpretation is speculative. The calf/cow ratio has declined consistently over the entire period and this could be due to forage becoming more limited as the wild buffalo population grows concurrently with feral and domestic buffalo and cattle populations, and because the Koshi River floods annually, destroying large areas of grasslands. Although the trend could be indicative of declining birth rates, in years in which there were no censuses birth rates could have been higher. The apparent decline is of concern but it is not, however, a

Table 1 The population structure of wild buffalo in Koshi Tappu Wildlife Reserve from 1976 to 2004, with the calf to cow ratio and the reference for each survey.

\begin{tabular}{|c|c|c|c|c|c|c|c|}
\hline \multirow[b]{2}{*}{ Year } & \multicolumn{2}{|c|}{ Adults } & \multicolumn{2}{|l|}{ Calves } & \multirow[b]{2}{*}{ Total } & \multirow[b]{2}{*}{ Calves/cows } & \multirow[b]{2}{*}{ Source } \\
\hline & Male & Female & 2nd year & 1st year & & & \\
\hline 1976 & 12 & 18 & 22 & 11 & 63 & 0.61 & Dahmer (1978) \\
\hline 1987 & 32 & 29 & 14 & 16 & 91 & 0.55 & Heinen (1993b) \\
\hline 1988 & 37 & 33 & 8 & 15 & 93 & 0.45 & Heinen (1993b) \\
\hline 2000 & 56 & 53 & 17 & 19 & 145 & 0.36 & Heinen \& Singh (2001) \\
\hline 2004 & 54 & 63 & 24 & 18 & 159 & 0.29 & This study \\
\hline
\end{tabular}


Table 3 The numbers of backcrossed buffalo counted in Koshi Tappu Wildlife Reserve in March 2000 (Heinen \& Singh, 2001) and March 2004 (this study).

\begin{tabular}{llllr} 
Year & Females & 2nd year calves & 1st year calves & Totals \\
\hline 2000 & 80 & 29 & 22 & 131 \\
2004 & 32 & 7 & 10 & 49 \\
\hline
\end{tabular}

major management issue until it can be ascertained whether it is real and, if so, what its causes are. In any case, the population is still growing.

The 2004 results indicated that males suffered more mortality overall than females despite the fact that females were still probably suffering more flood-related mortality. Of the 54 adult males estimated in 2004, 39 were counted directly and 15 were estimated from informant testimony. Heinen (1993b) and Heinen \& Singh (2001) had only estimated 6-8 males from informant testimony. If, therefore, we have overestimated the number of males in 2004 this would indicate that male mortality from 2000 to 2004 was even higher than indicated. Most large mammal populations have female-biased adult sex ratios (Bronson, 1989). The former warden reported his suspicion that some male wild buffalo were killed for meat in the previous few years. This was not documented directly but, in our 2000 survey (Heinen \& Singh, 2001), a young adult male was seen with a swollen leg. Two days later we found its carcass stripped. The death may have been natural, e.g. a fight with another male that lead to a septic wound, but it could also have happened by snaring. This carcass was evidence that some people will eat wild buffalo but we have no evidence of snares or other methods used to poach them inside the Reserve.

The overall population growth rate over 1976-2004 has been high, but variable within shorter time periods. Based on the Reserve records, the combined experience of ourselves and the technical team, interviews with other staff and assessments of the political situation in Nepal and managerial situation in the Reserve during various periods, we conclude that the observed variation in $r_{\mathrm{i}}$ over time is real. The high population growth rate of 1976-1987 corresponded to a period when human populations in the surrounding area were lower, protection was strong, Nepal was politically stable and the Koshi River did not change course. Low population growth during the time when JTH was resident in the Reserve (1986-1988) was characterized by a change of river course and flood mortality of females and calves (Heinen, 1993b). The high population growth over 1988-2000 occurred at a time when many managerial interventions were made, including the advent of buffer zone policies (Heinen \& Mehta, 2000), which were important for local development. The period overlapped with the democracy movement that led to several turbulent years (Raeper \& Hoftun, 1992) but other than for brief periods (e.g. part of 1990), it was a time when the Army was fully engaged in protecting the Reserve. Although rural human population densities in the region were increasing, management of the Reserve was active and the Koshi River did not change course.

The Park-People Project and Buffer Zone Policy, under implementation since the mid 1990s, have been effective in several ways (Heinen \& Mehta, 2000; Budhathoki, 2004; P. Kyastha, Buffer Zone Officer, pers. comm., 2004) and many villages in the area have benefited from programmes such as cottage industry development. This needs to continue and expand to ameliorate park-people conflicts that have characterized the management situation since the founding of the Reserve (Heinen, 1993a).

The Maoist insurgency has affected conservation programmes nationwide and especially since 2000 (Baral \& Heinen, 2006; Heinen \& Shrestha, 2006). The political instability is probably a factor in the recent decline of the population growth rate of wild buffalo. The Maoist insurgency created a volatile political situation (Thapa, 2003) in which the Army no longer patrols much of the Reserve. In addition to the infractions recorded during our survey there are many known or suspected cases of buffalo deliberately killed by poisoning, electrocution, or accidentally in highway deaths outside the Reserve, and suspected but unconfirmed reports of residents killing male buffalo for meat inside the Reserve. These are probably the reasons for both lower population growth and the shift to a female-biased sex ratio observed in 2004. Most buffalo killed recently by humans were males (Table 2). Some advances in protection were, however, also made. The Army shot some buffalo of domestic origin and, as a result, the backcrossed buffalo population is now lower than in 2000. Some cattle were also removed during and after our survey (Reserve records, 2004).

A number of interventions are needed to safeguard the wild buffalo population of Koshi Tappu Wildlife Reserve. We make the following non-prioritized recommendations:

1) Further genetic studies of wild buffalo are needed. Although a wild population exists in the Reserve (Flamand et al., 2003) a calf tested in that work and identified by JTH as of apparently wild stock proved to be a highly backcrossed, feral animal from a herd of known domestic origin that had been living in Koshi Tappu at least since the late 1950s and interbreeding with wild males. Although Dahmer (1978) and Heinen (2002) used behavioural and anatomical traits to differentiate wild from backcrossed buffalo, their use depends on spending considerable time comparing animals within and between herds and recognizing at least some individually. With lengthy periods between censuses such observations are 
thus not necessarily definitive and it is necessary for researchers to become reacquainted each time with all putative wild stock. Furthermore, as cross-breeding continues, backcrossed animals are likely to become more wild in both appearance and behaviour. Whether such individuals should be considered wild for conservation purposes needs to be further considered.

2) Continuous monitoring of the cattle population is needed. The Reserve should offer an annual amnesty for owners to remove stock but impose fines at other times.

3) As soon as possible given the insurgency, the Army should re-staff evacuated guard posts and resume patrols to reduce common infractions, such as grazing and wood cutting, and more serious offences such as killing buffalo for meat.

4) Because people can benefit from cross-breeding wild with domestic buffalo, allowing this legally without compromising conservation is beneficial. One project (Karki, 2003) has this as one of its goals. We do not recommend tranquilizing males and harvesting semen because it may result in more male mortality. Domestic females could, however, be permitted to enter to mate with bachelor males on a periodic quota system. Project funds could also be used to vaccinate permitted domestic stock.

5) Except for female domestic buffalo permitted to enter the Reserve to breed, the shoot-to-kill policy for domestic and backcrossed, tended buffalo should continue. Although controversial, it is the only aspect of direct management that has improved in the Reserve.

6) Buffer zone policies should continue and be expanded to include more villages and more education programmes. Although the hosting of a bird conservation week and a new visitor's centre are positive steps, public relations require improvement.

7) Because of the lack of long-term security in the Reserve and because it contains the only wild buffalo population in Nepal some individuals should be translocated, following recommended protocols (Stanley Price, 1989; Kleiman, 1996; IUCN, 1998), to form a second population elsewhere.

We believe that this last recommendation is the most critical for the secure future of the wild buffalo population of Nepal. Within the country there are four other protected areas within the species' historical range: Parsa Wildlife Reserve, Chitwan National Park, Bardia National Park and Sukla Phanta Wildlife Reserve (Fig. 1). Chitwan National Park would be the best site for relocation because (1) of its proximity to Koshi Tappu Wildlife Reserve, (2) of the quality of its available habitat, (3) it is a large National Park and thus receives better protection than a wildlife reserve (His Majesty' Government of Nepal, 1973), and (4) wild buffalo were known to occur there until the 1960s (Seidensticker, 1975). Although relations between local people and the Park have been strained (Sharma, 1990; Nepal \& Weber, 1995) this is also typical of other potential release sites (Bardia; Studsrod \& Wegge, 1995). Buffer zone policies are in place, the Park has a tourism industry that generates funding (Bookbinder et al., 1998), and Nepal has resources and expertise for large mammal translocations (Anon., 1999; Dinerstein, 2003). Heinen \& Kandel (2004) made recommendations for numbers, ages and sex classes for such a translocation, taking into consideration the need for group defensive behaviour because tiger Panthera tigris tigris occurs in Chitwan Park but has been absent from Koshi Tappu Wildlife Reserve since the 1960s.

\section{Acknowledgements}

We thank Officers and Staff of the DNPWC, especially T.M. Maskey (Director General), Narayan Paudel (Deputy Director General) and Shyam Bajhimaya (Senior Ecologist) for permitting this study. We thank Sameer Karki and IUCN - Nepal for funding. Ganga Ram Singh, Lal Bahadur Bhandari and Pankaj Kyastha served as members of the Technical Team. Chandra Shrestha, T.N. Shrestha, and Rabindra K. and Raj Kumar Singh provided invaluable help in the field.

\section{References}

Amano, W., Miyakoshi, Y., Takada, T., Kikkawa, Y. \& Suzuki, H. (1994) Genetic variants of ribosomal DNA and mitochondrial DNA between swamp and river buffaloes. Animal Genetics, 25(Suppl. 1), 29-36.

Anon (1999) Ten Years Retrospective Report: 1989-1999. King Mahendra Trust for Nature Conservation, Kathmandu, Nepal.

Baral, N. \& Heinen, J.T. (2006) The Maoist People's War and conservation in Nepal. Politics and the Life Sciences, 24, 1-11.

Barker, J.S.F., Moore, S.S., Hetzel, D.J.S., Evans, D., Tan, S.G. \& Byrne, K. (1997) Genetic diversity of Asian water buffalo (Bubalus bubalis): microsatellite variation and a comparison with protein-coding loci. Animal Genetics, 28, 103-115.

Bookbinder, M.P., Dinerstein, E., Rijal, A., Cauley, H. \& Rajouria, A. (1998) Ecotourism's support of biodiversity conservation. Conservation Biology, 12, 1399-1404.

Bronson, F.H. (1989) Mammalian Reproductive Biology. University of Chicago Press, Chicago, USA.

Budhathoki, P. (2004) Linking communities with conservation in developing countries: buffer zone management initiatives in Nepal. Oryx, 38, 334-341.

Choudury, A. (1994) The decline of water buffalo in north-east India. Oryx, 28, 70-73.

Clutton-Brock, J. (1989) A Natural History of Domesticated Mammals. University of Texas Press, Austin, USA. 
Corbet, G.B. \& Hill, J.E. (1992) The Mammals of the Indomalayan Region. Natural History Museum Publications, Oxford University Press, Oxford, UK.

Dahmer, T.D. (1978) Status and distribution of the wild Asian buffalo (Bubalus bubalis) in Nepal. MS thesis, University of Montana, Missoula, USA.

Dinerstein, E. (2003) Return of the Unicorns. Columbia University Press, New York, USA.

Divakar, H.K. \& Bhusan, B. (1988) Status of the wild Asiatic buffalo, Bubalus bubalis, in the Raipur and Bastar Districts of Madya Pradesh. Technical Report of the Bombay Natural History Society. SANCF Report No. 3/1988, Bombay, India.

Flamand, J.R.B., Vankan, D., Ghaire, G.P., Duong, H. \& Barker, J.S.F. (2003) Genetic identification of wild Asian water buffalo in Nepal. Animal Conservation, 6, 265-270.

Groves, C.P. (1981) Systematic relationships in the Bovini (Artiodactyla, Bovidae). Zeitschrift fur Zoologische Systematik und Evolutionsforschung, 19, 264-278.

Hedges, S. (1995) Asian Wild Cattle and Buffalo: Draft Status Report and Conservation Action Plan (Parts I and II). Unpublished Report, IUCN Gland, Switzerland.

Heinen, J.T. (1993a) Park-people relations in Koshi Tappu Wildlife Reserve, Nepal: a socio-economic analysis. Environmental Conservation, 20, 25-34.

Heinen, J.T. (1993b) Population viability and management recommendations for wild water buffalo (Bubalus bubalis) in Koshi Tappu Wildlife Reserve, Nepal. Biological Conservation, 65, 29-34.

Heinen, J.T. (2002) Phenotypic and behavioural characteristics used to identify wild buffalo from feral backcrosses in Nepal. Journal of the Bombay Natural History Society, 99, 173-183.

Heinen, J.T. \& Kandel, R. (2004) A Census and Conservation Action Plan for Wild Buffalo in Nepal. DNPWC and IUCN Nepal, Kathmandu.

Heinen, J.T. \& Mehta, J.N. (2000) Emerging issues in legal and procedural aspects of buffer zone management with case studies from Nepal. Journal of Environment and Development, 9, 45-67.

Heinen, J.T. \& Shrestha, S.K. (2006) Evolving policies for conservation: an historical profile of the protected area system of Nepal. Journal of Environmental Planning and Management, 49, 41-58.

Heinen, J.T. \& Singh, G.R. (2001) A census and some management implications for wild buffalo in Nepal. Biological Conservation, 101, 391-394.

Heinen, J.T. \& Srikosamatara, S. (1996) Status and protection of Asian wild cattle and buffalo. Conservation Biology, 10, 931-934.

His Majesty's Government of Nepal (1973) National Parks and Wildlife Conservation Act. Nepal Gazette, 2029, 11-28.

IUCN (1998) Guidelines for Re-introduction. IUCN/SSC Re-introduction Specialist Group, Gland, Switzerland and Cambridge, UK.

IUCN (2006) IUCN Red List of Threatened Species. IUCN, Gland, Switzerland [http:/ /www.redlist.org, accessed 16 May 2006]

Karki, S. (2003) Community Incentives to Reduce Land Use Conflicts and Conserve Biodiversity in Nepal. Proposal submitted to the Global Environmental Facility by IUCN Nepal Program, Kathmandu, Nepal.

Kleiman, D.G. (1996) Reintroduction programs. In Wild Animals in Captivity: Principles and Techniques (eds D.G. Kleiman, M.E.
Allen, K.V. Thompson \& S. Lumpkin), pp. 297-305. University of Chicago Press, Chicago, USA.

Muley, P.D. (2001) Genetic and morphometric studies to differentiate between wild and domestic Asian water buffalo (Bubalus bubalis) and their hybrids in Kaziranga National Park, Assam, India. PhD thesis, University of Wisconsin, Madison, USA.

Nepal, S.K. \& Weber, K.E. (1995) Managing resources and resolving conflict: national parks and local people. International Journal of Sustainable Development and World Ecology, 2, 11-25.

Nowak, R.M. (1999) Walker's Mammals of the World. 6th edition. Johns Hopkins University Press, Baltimore, USA.

Raeper, W. \& Hoftun, M. (1992) Spring Awakening: An Account of the 1990 Revolution in Nepal. Penguin Books, New Delhi, India.

Read, B. (1999) Bison, Buffalo and Cattle Taxon Advisory Group. Unpublished Regional Collection Plan, American Zoo and Aquarium Association, Washington, DC, USA.

Sah, J.P. (1997) Koshi Tappu Wetlands: Nepal's Ramsar Site. IUCN Southeast Asia Regional Coordination Office, Bangkok, Thailand.

Seidensticker, L. (1975) Ungulate Populations in Chitwan Valley, Nepal. Unpublished Report, Office of Zoological Research, National Zoological Park, Smithsonian Institution, Washington, DC, USA.

Sharma, U.R. (1990) An overview of park/people interactions in Royal Chitwan National Park. Landscape and Urban Planning, 19, 133-144.

Shrestha, T.K. (1997) Mammals of Nepal with Reference to Those of India, Bangladesh, Bhutan and Pakistan. Bimala Shrestha, Kathmandu, Nepal.

Stanley Price, M.R. (1989) Animal Reintroductions: The Arabian Oryx in Oman. Cambridge University Press, Cambridge, UK.

Studsrod, J.E. \& Wegge, P. (1995) Park-people relationships: the case of damage caused by park animals around Royal Bardia National Park, Nepal. Environmental Conservation, 22, 133-142.

Suwal, R.N. (1993) Koshi Tappu Wildife Reserve: Conservation Issues and Management Measures. Unpublished Report to IUCN, Kathmandu, Nepal.

Thapa, D. (2003) A Kingdom Under Siege: Nepal's Maoist Insurgency, 1996 to 2003. The Printhouse, Kathmandu, Nepal.

Tulloch, D.G. (1979) The water buffalo, Bubalus bubalis, in Australia: reproduction and parent-offspring behaviour. Australian Wildlife Research, 6, 265-287.

\section{Biographical sketches}

Joel T. Heinen's research interests are in park-people interactions and large mammal conservation in Asia. He is an member of IUCN's Species Survival Commission and the Mountain Forum, in addition to numerous other scientific and professional organizations.

Ramchandra Kandel's research interests are in the ecology and conservation of the large mammals of South Asia. He has held various posts as Assistant Warden and Warden in Nepal, including that of Koshi Tappu Wildlife Reserve. 